\title{
Publishers soldier on despite electronic bugs
}

\section{Rex Dalton, San Diego}

It would have made the perfect gift - were it not for the vagaries of electronic publishing. Attending the wedding of a former doctoral student, neuroscientist John Salamone from the University of Connecticut had hoped to confirm publication of a paper the pair had co-authored. Instead, he brought news of a problem that has left many other researchers equally frustrated software used by the journal to keep track of the manuscript had misfired.

As scientific publishers react to the opportunities offered by the Internet and online publishing, electronic systems are pervading every aspect of the publication process. But with these advances often come teething troubles.

For Salamone, that meant a lengthy delay. The team submitted its paper to Neuroscience last November, but in April the journal's editors admitted that the manuscript-tracking software had lost both the manuscript and the reviewers' comments. "This was supposed to be a fast-track publication," says Brian Carlson, Salamone's former student who is now at the University of California, Los Angeles.

It took until June, a month after Carlson's wedding, for the paper to be accepted for publication. In the meantime, Carlson was turned down for a grant from a private foundation - which he attributes in part to the delayed publication - and a co-author had to hold back a second paper that couldn't be submitted until Carlson's was published.

The episode is fairly typical of the problems encountered as scientific journals move deeper into the electronic age, researchers say. Robert Dickinson, president of the American Geophysical Union (AGU), told the society's members in a statement earlier this month: "The most critical problem that has been facing AGU is its transition to electronic publishing."

A major issue for journals is keeping track of manuscripts. Because the publication process varies so much between journals, off-the-shelf software packages tend not to fit the bill, so scientific publishers often have to prepare or commission bespoke software for their titles. And, as with all customized software, this carries an element of risk.

Neuroscience, which is published by Dutch company Elsevier Science on behalf of the Paris-based International Brain Research Organization, had been testing a manuscript-tracking system called SMARTWorks, which was developed several years ago in San Diego. The system was written for Elsevier, and is unrelated to commercial software sold by SMARTworks.com of Dayton, Ohio.

David Amaral, a neuroscientist at the

University of California, Davis, and chief editor of Neuroscience, says that the system developed some "quite bizarre" problems, and the journal stopped using it in March. Elsevier officials say they have since reduced their reliance on SMARTWorks and are trying other systems.

Even when the software works, some scientific publishers have seen their software suppliers go bust, leaving them without any technical back-up. This happened to the European Journal of Neuroscience, published for the Federation of European Neuroscience Societies by the UK company Blackwell Science, when the software supplier it was

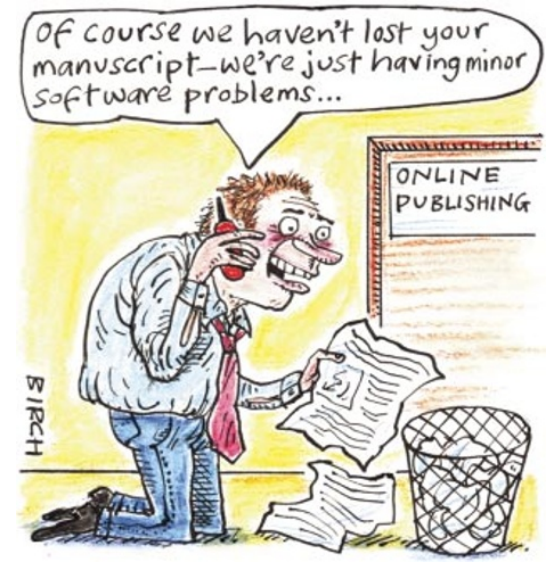

using, PaperPath of Massachusetts, closed its doors last September.

"It was working beautifully, absolutely perfectly," says Barry Everitt, a behavioural neuroscientist at the University of Cambridge and editor-in-chief of the bimonthly journal. "Then the company evaporated and our database went down.” Everitt says his journal fell a month behind on its publishing schedule, after temporarily reverting to the use of paper manuscripts. "We recovered, but it was very damaging," he recalls.

The new systems are also raising concerns about security. In May, for example, a researcher at the National Institutes of Health told the Nature Publishing Group (NPG), publisher of Nature, that one of his postdocs had inadvertently accessed two papers by other authors while "playing around" with their own submission to Nature Cell Biology. The journal uses a manuscript system developed for NPG. Ruth Wilson, peer-review manager at NPG, says that security on the system has now been tightened so that the problem cannot recur.

Publishers are hoping researchers will be patient, and say that the transition to fullblown electronic publishing will eventually benefit everyone. "We are all running into problems as we scale up," says Jasna Markovac, a director of Elsevier based in San Diego. "But we will find solutions."

\section{US panel split on research cloning}

Kendall Powell, Washington

President George Bush's bioethics council

has issued a split decision on whether to ban cloning for research purposes - increasing the likelihood that Congress will fail to legislate on cloning this year.

The President's Council on Bioethics issued a report on 11 July that unanimously endorsed a ban on human cloning to produce children. Ten of the council members recommended a four-year moratorium on cloning for research purposes, sometimes referred to as therapeutic cloning, whereas seven said that research cloning should proceed once appropriate regulations are in place.

Leon Kass, chairman of the council and a philosopher at the University of Chicago, says he hopes the president will consider both recommendations - while recognizing that one is the majority opinion. "The president asked for a debate of the issues and he's got it," Kass says.

But it is the Congress that must pass any law to ban cloning. And early indications are that the divided recommendation will entrench the deadlock that has so far prevented the Senate from passing any legislation on the issue.

Gene Tarne, a spokesman for Americans to Ban Cloning, a coalition of anticloning groups, claims that the majority recommendation will help to muster support for a moratorium on human cloning in the Senate. "The four-year period will give time for discussion and encourage scientists to expand work on alternative research," he says.

But Kevin Wilson, director of public policy for the American Society for Cell Biology, which supports cloning for research purposes, says a moratorium would amount to the same thing as an outright ban. He draws comfort from the fact that seven members of a panel named by Bush supported the society's position. "You have a sizeable number of presidentially appointed members thinking that the research should continue," Wilson says.

In a rare display of unity, lobbyists on both sides conceded that the split decision reflected the diversity of opinion among the US public on cloning for research. 